\title{
Effects of calcium and plant sterols on serum lipids in obese Zucker rats on a low-fat diet
}

\author{
Timo Vaskonen $^{1 *}$, Eero Mervaala ${ }^{1}$, Ville Sumuvuori ${ }^{1}$, Tuulikki Seppänen-Laakso ${ }^{2}$ and \\ Heikki Karppanen ${ }^{1}$ \\ ${ }^{1}$ Institute of Biomedicine, Pharmacology, University of Helsinki, Finland \\ ${ }^{2}$ Department of Pharmacy, University of Helsinki, and VTT Biotechnology, Espoo, Finland
}

(Received 15 March 2001 - Revised 3 November 2001 - Accepted 9 November 2001)

\begin{abstract}
Ca may interfere with fat and cholesterol metabolism through formation of insoluble soaps with fatty and bile acids in the intestine. In the present study, we examined the effects of different dietary $\mathrm{Ca}$ levels on the serum lipid profile and cholesterol metabolism in obese Zucker rats fed a low-fat diet. We also tested whether dietary $\mathrm{Ca}$ interfered with the lipid-lowering effects of a pine oil-derived plant sterol mixture. Increase in dietary Ca intake from 0.2 to $0.8 \%$, and further to $2.1 \%(\mathrm{w} / \mathrm{w})$ dose-dependently decreased serum total cholesterol $(\mathrm{r}-0.565, P=0.002, n 27)$, LDL-cholesterol ( $\mathrm{r}-0.538, P=0.006, n 25)$, and triacylglycerol $(\mathrm{r}-0.484, P=0.014, n 25)$ concentrations, and increased HDL-cholesterol (r $0.478, P=0.016, n$ 25) and HDL:LDL cholesterol (r 0.672, $P<0.001, n 25)$ in rats fed a $1 \%$ cholesterol diet. Analysis of serum campesterol:cholesterol and sitosterol:cholesterol suggested that $\mathrm{Ca}$ dose-dependently increased intestinal cholesterol absorption ( $\mathrm{r}$ 0.913, $P<0.001, n$ 18), whereas serum desmosterol:cholesterol and lathosterol:cholesterol indicated that $\mathrm{Ca}$ dose-dependently increased endogenous cholesterol synthesis (r 0.691, $P=0.003, n$ 18). Therefore, the decrease of serum LDL-cholesterol appeared to be due to Ca-induced increase in the conversion of cholesterol to bile acids. The increase in $\mathrm{Ca}$ intake did not interfere with the beneficial effects of plant sterols on serum total cholesterol, LDL-cholesterol and HDL-cholesterol concentrations. The high-Ca diet with plant sterol supplementation further increased the HDL-cholesterol concentration and HDL:LDL cholesterol. The present findings indicate that the beneficial effects of dietary $\mathrm{Ca}$ on the serum lipid profile during a low-fat diet are dose-dependent, and resemble those of bile acid sequestrants. Increased dietary $\mathrm{Ca}$ did not impede the lipid-lowering effects of natural plant sterols.
\end{abstract}

Calcium: Cholesterol: Plant sterols: Zucker rats

Increased dietary intake of $\mathrm{Ca}$ is currently recommended for the general population to lower the risk of hypertension and osteoporosis (Kotchen \& McCarron, 1998; Krauss et al. 2000). Some previous studies have indicated that dietary Ca supplementation also lowers serum cholesterol (Yacowitz et al. 1965; Denke et al. 1993; Denke \& Grundy, 1995). The mechanism is somewhat unclear, but it has been suggested that $\mathrm{Ca}$ decreases the absorption of dietary cholesterol by forming non-absorbable chelates with fatty acids and/or bile acids (Yacowitz et al. 1965; Saunders et al. 1988; Denke et al. 1993; Denke \& Grundy, 1995; Holt, 1999). It is also postulated that saturated fatty acids increase serum cholesterol by inhibiting the receptormediated uptake of LDL into the liver (Kris-Etherton et al. 1988; Grundy \& Denke, 1990). The lipid-lowering effect of Ca may thus also be linked to changes in cholesterol uptake and metabolism in the liver.

Increasing the intake of plant sterols is another dietary approach to lowering the risk of cardiovascular diseases (Ikeda \& Sugano, 1998). Sitostanol, the saturated derivative of the most common plant sterol, $\beta$-sitosterol, has produced a moderate lowering of circulating cholesterol levels in most trials in patients with mild hypercholesterolaemia (Nguyen, 1999; Law, 2000). Both sitostanol and $\beta$-sitosterol are believed to lower serum cholesterol mainly extrinsically by competing with cholesterol for micellar solubilization and, thus, blocking cholesterol absorption from the intestinal lumen (Ikeda \& Sugano, 1998; Nguyen, 1999; Law, 2000). However, owing to the reactive increase of cholesterol synthesis in the liver, only mild lowering of 
serum cholesterol by plant sterols is achieved (Ikeda \& Sugano, 1998; Nguyen, 1999; Law, 2000).

Previously, we showed that (1) a 'human-like' serum lipid profile could be induced in the obese Zucker rat by increasing the dietary intake of cholesterol and saturated fat; (2) plant sterol supplementation partly counteracted this diet-induced increase in serum total and LDL cholesterol; (3) dietary $\mathrm{Ca}$ and $\mathrm{Mg}$ but not $\mathrm{Na}$ and $\mathrm{K}$ supplementation was able to augment the effect of the plant sterols (Vaskonen et al. 2001).

In the present study, we used the same animal model for a more thorough examination of the effects and interactions of dietary cholesterol, plant sterols and $\mathrm{Ca}$ during a low-fat diet. In particular, Ca was given in three different dietary levels to evaluate dose-response relationships. Its effects of intestinal cholesterol absorption and endogenous cholesterol synthesis were estimated by measuring the serum concentrations of plant sterols and two cholesterol precursors. We also investigated whether dietary $\mathrm{Ca}$ interfered with the lipid-lowering effects of natural plant sterols.

\section{Methods}

\section{Experimental animals, diets and sample preparation}

Ninety-seven female 6-9-week-old obese Zucker rats (Harlan, Oxon., England) were used. Three animals were housed per cage in an animal laboratory (illuminated from 06.30 to 18.30 hours, room temperature $22-24^{\circ} \mathrm{C}$ ). The procedures and protocols of the study were in accord with our institutional guidelines and were approved by the Animal Experimentation Committee of the Institute of Biomedicine, University of Helsinki, Finland.

The experimental diets used in the present study were produced by adding cholesterol (Sigma, St Louis, MO, USA), $\mathrm{CaCl}_{2}$ (University Pharmacy, Helsinki, Finland), $\mathrm{CaCO}_{3}$ (University Pharmacy) and a pine oil-derived plant sterol mixture to a commercial rat chow (Altromin Spezial Diät C1031; Altromin GmbH, Lage, Germany). The plant sterol mixture was kindly provided by Mr Matti Hautala of UPM-Kymmene, Lappeenranta, Finland. The chemical composition of the powder (w/w) was as follows: sitosterol $79.2 \%$, sitostanol $11.4 \%$, campesterol $7.5 \%$, campestanol $1.2 \%$, cycloartenolol $0.5 \%$ and $\delta-7$-avenasterol $0.2 \%$. The different components were mixed with powdered rat chow and moistened with water, using an industrial dough mixer. The chow preparations were then packed in $1 \mathrm{~d}$ portions and stored at $-20^{\circ} \mathrm{C}$.

Experiment 1. The effect of increasing amounts of dietary cholesterol ranging from 0 to $4 \%$ (w/w) on serum cholesterol was examined. Rats matched for body weight and serum cholesterol (eight rats in each group) were divided into five groups to receive the following diets for 2 weeks: (1) low-cholesterol control diet; (2) $0.5 \%$ cholesterol diet; (3) $1.0 \%$ cholesterol diet; (4) $2.0 \%$ cholesterol diet; (5) $4.0 \%$ cholesterol diet.

Experiment 2. The effect of increasing amounts of dietary plant sterols ranging from 0 to $4 \%(\mathrm{w} / \mathrm{w})$ on serum cholesterol was examined. The same animals that were used in experiment 1 were used. After a 2-week washout period (all rats on low-cholesterol control diet), the rats matched for body weight and serum cholesterol (six or seven rats in each group) were divided into six groups to receive the following diets for 4 weeks: (1) low-cholesterol control diet; (2) $1.0 \%$ cholesterol diet; (3) $1.0 \%$ cholesterol diet supplemented with $0.5 \%$ plant sterols; (4) $1.0 \%$ cholesterol diet supplemented with $1.0 \%$ plant sterols; (5) $1.0 \%$ cholesterol diet supplemented with $2.0 \%$ plant sterols; (6) $1.0 \%$ cholesterol diet supplemented with $4.0 \%$ plant sterols.

Experiment 3. The effect of dietary $\mathrm{Ca}$ level on serum cholesterol was examined in rats receiving the $1.0 \%$ cholesterol diet. The rats matched for body weight and serum cholesterol (eight or nine rats in each group) were divided into three groups to receive the following diets for 8 weeks: (1) low-Ca diet (Ca $0.2 \%$ w/w); (2) moderate-Ca $\operatorname{diet}(\mathrm{Ca} 0.8 \% \mathrm{w} / \mathrm{w})$; (3) high-Ca diet (Ca $2.1 \% \mathrm{w} / \mathrm{w})$.

Experiment 4. The influence of dietary $\mathrm{Ca}$ level on the effects of plant sterols were examined in rats receiving the $1.0 \%$ cholesterol diet. The rats matched for body weight and serum cholesterol (seven or eight rats in each group) were divided into four groups to receive the following diets for 8 weeks: (1) low-Ca diet (Ca $0.2 \% \mathrm{w} / \mathrm{w})$; (2) low-Ca (Ca $0.2 \% \mathrm{w} / \mathrm{w})$ plus plant sterols $(1.0 \% \mathrm{w} / \mathrm{w}) \operatorname{diet}$; (3) high-Ca diet (Ca 2.1\% w/w); (4) high-Ca $(\mathrm{Ca} 2.1 \% \mathrm{w} / \mathrm{w})$ plus plant sterols $(1.0 \% \mathrm{w} / \mathrm{w})$ diet.

The rats had free access to the food and tap water at all times. Blood samples from a superficial vein of the foot were taken for serum cholesterol measurements during the experiments. The general well-being of the animals was checked daily, and they were weighed once a week. At the end of the experiments, the rats were killed by decapitation. Blood samples were taken into two chilled tubes on ice. The whole-blood samples were stored at $-20^{\circ} \mathrm{C}$ and the serum samples at $-80^{\circ} \mathrm{C}$ until assayed. In experiment 2 , the heart, kidneys, liver, spleen, uterus, ovaries and brain were dissected, washed with ice-cold saline, blotted dry and weighed for evaluation of possible toxic effects of the natural plant sterol mixture that was used in all the experiments.

\section{Biochemical measurements}

Serum cholesterol was measured during the experiments using an automatic analyser (Reflotron $\AA$; Boehringer Mannheim, Germany). Serum lipids from the samples taken at the end of the experiments were analysed by an accredited laboratory, United Laboratories Ltd., Helsinki, Finland (Hitachi 912 Automatic Analyzer; Hitachi Ltd., Tokyo, Japan). An excellent correlation in serum cholesterol between the Reflotron and standard laboratory measurements was found (r 0.951, $P<0.001, n$ 64). The blood count was also analysed by this same laboratory. The concentrations of serum non-cholesterol sterols were analysed by GC-MS using a Hewlett-Packard 5890 GC device equipped with an NB-54 fused-silica capillary column $(15 \mathrm{~m} \times 0.20 \mathrm{~mm}$ i.d.; Nordion, Helsinki, Finland $)$ and interfaced with a Hewlett-Packard 5970A MS detector operating in electron impact mode $(70 \mathrm{eV})$. The column oven was programmed from $230^{\circ} \mathrm{C}$ to $285^{\circ} \mathrm{C}$ at $10^{\circ} \mathrm{C} / \mathrm{min}$ and injector and detector were at $285^{\circ} \mathrm{C}$. The 
lipids from serum samples $(200 \mu l)$ were extracted with chloroform-methanol $(2: 1)$ and transesterified with sodium methoxide. The released free sterols were trimethylsilylated (Gylling et al. 1999) and were quantified by the single ion monitoring technique using $\mathrm{m} / \mathrm{z} 129$ (cholesterol, campesterol and $\beta$-sistosterol), $\mathrm{m} / \mathrm{z}$ 217 ( $\beta$-sitostanol), $\mathrm{m} / \mathrm{z} 343$ (desmosterol), $\mathrm{m} / \mathrm{z} 255$ (lathosterol) and $\mathrm{m} / \mathrm{z} 217$ (5- $\alpha$-cholestane, internal standard) as selected ions.

\section{Statistics}

Data for dose-response relationships were analysed by calculating Pearson correlation coefficients, followed by a two-tailed significance test. Between-group comparisons were carried out by one-way ANOVA supported by the Fisher's least significant difference test. Differences between means that had a value of $P<0.05$ were considered significant. The data were analysed with SYSTAT Statistical Software (SYSTAT Inc., Evanston, IL, USA). The results are expressed as means with their standard errors.

\section{Results}

Dose-response relationships for dietary cholesterol and plant sterols (experiments 1 and 2)

Dietary cholesterol supplementation dose-dependently increased serum cholesterol in obese Zucker rats (Fig. 1A). For a statistically significant effect $1 \%$ dietary cholesterol was required, and there was a strong positive correlation between the food and serum cholesterol concentrations (r 0.742, $P<0.001, n 40)$.

Plant sterol supplementation dose-dependently decreased serum cholesterol in obese Zucker rats receiving the $1 \%$ cholesterol diet (Fig. 1B). For a significant effect, $1 \%$ plant sterol supplementation was required, and $4 \%$ completely prevented the diet-induced increase in serum cholesterol. Serum cholesterol in the group receiving no cholesterol or plant sterols was $3 \cdot 1$ (SE 0.2$)$ mmol/l. There was a strong inverse correlation between the food plant sterol and serum cholesterol concentrations ( $\mathrm{r}-0.692$, $P<0 \cdot 001, n 34)$. The diet containing $1 \%$ cholesterol and no plant sterols produced a higher serum cholesterol level than was observed in experiment 1 , but the treatment time was longer (4 weeks) and the rats were older than in experiment 1 (the same rats were used). No changes in general wellbeing of the animals, body weight, weight of internal organs or blood count were observed, even at the highest $(4 \%)$ dietary plant sterol level (Table 1).

\section{Effects of calcium (experiment 3)}

Increase in dietary $\mathrm{Ca}$ intake from 0.2 to $0.8 \%$ to $2.1 \%$ dose-dependently decreased the concentrations of serum total cholesterol ( $\mathrm{r}-0.565, P=0.002, n$ 27), LDLcholesterol $(\mathrm{r}-0.538, P=0.006, n 25)$ and triacylglycerol ( $\mathrm{r}-0.484, P=0 \cdot 014, n 25)$, and increased HDL-cholesterol (r 0.478, $P=0.016, n 25)$, HDL : total cholesterol (r 0.672, $P<0.001, n 25)$, and HDL : LDL (r 0.447, $P=0 \cdot 025, n$ 25) in rats fed a $1 \%$ cholesterol diet (Fig. 2, Table 2). Ca also dose-dependently increased the ratios of two cholesterol precursors to cholesterol : desmosterol : cholesterol (r 0.691, $P=0.003, n$ 18; Fig. 3) and lathosterol : cholesterol (r 0.619, $P=0.011, n 18)$. Furthermore, Ca dose-dependently increased the ratios of serum plant sterols to cholesterol: campesterol : cholesterol (r 0.812, $P<0.001, n$ 18; Fig. 3), campestanol: cholesterol (r 0.627, $P=0.009, n$ 18), sitosterol: cholesterol ( $\mathrm{r}$ 0.913, $P<0.001, \quad n$ 18) and sitostanol: cholesterol (r 0.646, $P=0.007, n$ 18).
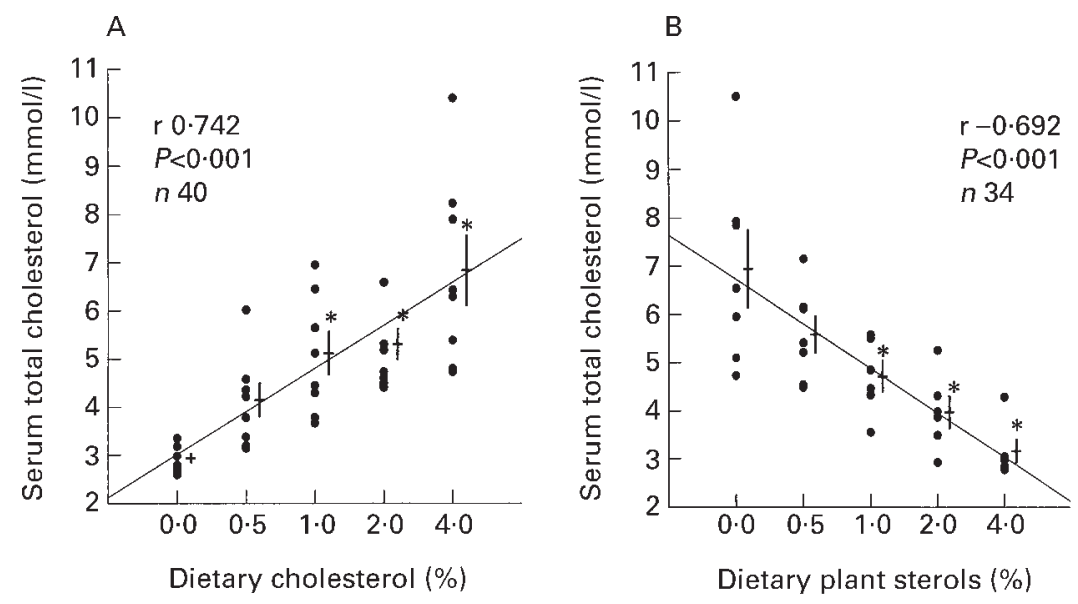

Fig. 1. Serum total cholesterol concentrations of obese Zucker rats (A) after 2 weeks on diets with different cholesterol levels, and (B) after 4 weeks on diets with $1 \%$ cholesterol and different plant sterol levels. Horizontal bars beside each group are group means with their standard errors represented by vertical bars. ${ }^{\star} P<0.05 \mathrm{~V}$. nocholesterol group (A) or no-plant sterol group (B). For details of diets and procedures, see p. 240. 
Table 1. Experiment 2. Wet weights of internal organs and blood count of obese Zucker rats after 4 weeks on the different diets*

(Mean values with their standard errors for six or seven rats per group)

\begin{tabular}{|c|c|c|c|c|c|c|c|}
\hline \multirow[t]{2}{*}{ Diet ... } & \multicolumn{2}{|c|}{ Low cholesterol } & \multicolumn{2}{|c|}{$1 \%$ Cholesterol } & \multicolumn{2}{|c|}{$\begin{array}{c}1 \% \text { Cholesterol }+ \\
4 \% \text { plant sterols }\end{array}$} & \multirow[b]{2}{*}{ ANOVA } \\
\hline & Mean & SE & Mean & SE & Mean & SE & \\
\hline Total body weight (g) & 482 & 11 & 480 & 10 & 482 & 10 & 0.430 \\
\hline Heart $(g)$ & 0.78 & 0.02 & 0.79 & 0.02 & 0.76 & 0.01 & 0.652 \\
\hline Kidneys (g) & $2 \cdot 1$ & 0.1 & $2 \cdot 1$ & 0.1 & $2 \cdot 1$ & 0.1 & 0.441 \\
\hline Liver $(\mathrm{g})$ & $13 \cdot 8$ & 0.8 & $15 \cdot 3$ & 0.9 & $15 \cdot 0$ & 0.7 & 0.598 \\
\hline Thymus (g) & 0.58 & 0.12 & 0.56 & 0.08 & 0.51 & 0.10 & 0.960 \\
\hline Adrenals (g) & 0.073 & 0.002 & 0.077 & 0.003 & 0.078 & 0.004 & 0.449 \\
\hline Spleen (g) & 0.80 & 0.04 & 0.85 & 0.03 & 0.87 & 0.06 & 0.543 \\
\hline Uterus $(\mathrm{g})$ & 0.71 & 0.04 & 0.73 & 0.03 & 0.64 & 0.03 & 0.059 \\
\hline Ovaries (g) & 0.14 & 0.01 & 0.15 & 0.01 & 0.13 & 0.01 & 0.182 \\
\hline Forebrain (g) & 1.70 & 0.02 & 1.70 & 0.02 & 1.65 & 0.01 & 0.278 \\
\hline Haemoglobin (g/l) & 138 & 2 & 141 & 4 & 138 & 4 & 0.760 \\
\hline Haematocrit (\%) & $46 \cdot 0$ & 1.0 & 45.5 & $1 \cdot 2$ & $45 \cdot 3$ & $1 \cdot 3$ & 0.893 \\
\hline Erythrocytes (×10 $12 / l)$ & 7.7 & 0.3 & 7.5 & 0.4 & $7 \cdot 7$ & 0.2 & 0.839 \\
\hline $\mathrm{MCHC}(\mathrm{g} / \mathrm{l})$ & 300 & 5 & 311 & 7 & 305 & 3 & 0.472 \\
\hline $\mathrm{MCH}(\mathrm{pg})$ & $17 \cdot 8$ & 0.4 & $19 \cdot 0$ & 0.9 & $18 \cdot 3$ & 0.3 & 0.344 \\
\hline MCV (fl) & $59 \cdot 8$ & 1.7 & $61 \cdot 0$ & 1.8 & $59 \cdot 0$ & 0.8 & 0.664 \\
\hline Leucocytes (×109/I) & 3.26 & $1 \cdot 13$ & 4.08 & 0.48 & $4 \cdot 20$ & $1 \cdot 10$ & 0.761 \\
\hline Neutrophils (\%) & $40 \cdot 4$ & 3.5 & 32.8 & $2 \cdot 3$ & $30 \cdot 1$ & 3.8 & 0.093 \\
\hline Eosinophils (\%) & $2 \cdot 40$ & 0.51 & 2.75 & 0.85 & 1.25 & 0.25 & 0.232 \\
\hline Basophils (\%) & 0.00 & 0.00 & 0.00 & 0.00 & 0.00 & 0.00 & - \\
\hline Lymphocytes (\%) & $56 \cdot 8$ & 3.3 & 63.8 & 2.5 & 67.8 & 4.3 & 0.114 \\
\hline Monocytes (\%) & 0.60 & 0.25 & 0.75 & 0.25 & 1.00 & 0.00 & 0.431 \\
\hline Thrombocytes $\left(\times 10^{9} / \mathrm{I}\right)$ & 782 & 226 & 1405 & 234 & 1026 & 281 & 0.240 \\
\hline
\end{tabular}

$\mathrm{MCHC}$, mean cellular haemoglobin concentration; $\mathrm{MCH}$, mean cellular haemoglobin; MCV, mean cell volume.

${ }^{\star}$ For details of diets and procedures, see p. 240.

Effects of plant sterols alone and with calcium (experiment 4)

The differences in serum cholesterol between the low- and high-Ca diets were similar to those observed in experiment 3 (Table 3). Plant sterols during the low-Ca diet produced a $35 \%$ decrease in serum total cholesterol $(P=0.002)$, a $60 \%$ decrease in LDL-cholesterol $(P<0.001)$ and a $70 \%$ increase in HDL-cholesterol $(P=0.029)$. Plant sterols during the high-Ca diet increased serum HDL-cholesterol by $40 \% \quad(P=0.001)$ and markedly improved the HDL : LDL ratio $(P=0.002)$. Plant sterol supplementation increased the desmosterol:cholesterol and lathosterol: cholesterol ratios during the low-Ca diet $(P=0.008$ and
A

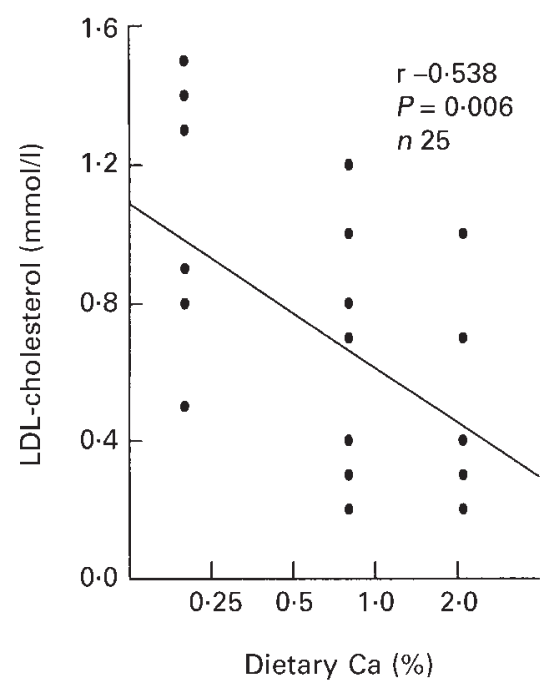

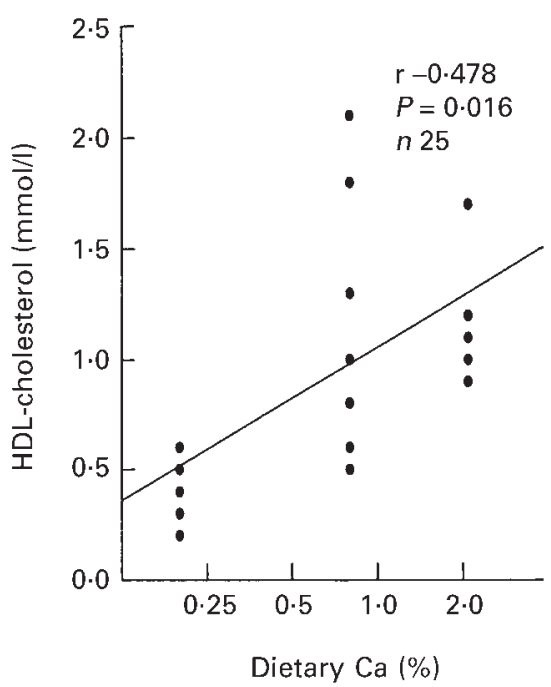

c

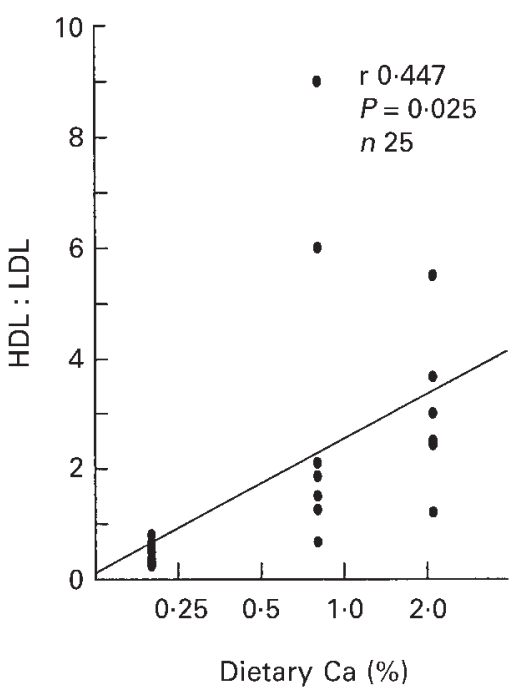

Fig. 2. Dose-dependent effects of dietary calcium on serum LDL- and HDL-cholesterol and LDL: HDL cholesterol in obese Zucker rats after 8 weeks on the different diets. For details of diets and procedures, see p. 240. 
Table 2. Experiment 3. Serum total-, LDL- and HDL-cholesterol, triacylglycerols, cholesterol precursors and plant sterol concentrations of obese Zucker rats after 8 weeks on the $1 \%$ cholesterol diets with different calcium levelsł

(Mean values with their standard errors for eight or nine rats per group)

\begin{tabular}{|c|c|c|c|c|c|c|c|}
\hline \multirow[t]{2}{*}{ Diet ... } & \multicolumn{2}{|c|}{$\begin{array}{c}\text { Low Ca } \\
(0.2 \% \mathrm{w} / \mathrm{w})\end{array}$} & \multicolumn{2}{|c|}{$\begin{array}{c}\text { Moderate Ca } \\
(0.8 \% \mathrm{w} / \mathrm{w})\end{array}$} & \multicolumn{2}{|c|}{$\begin{array}{c}\text { High Ca } \\
(2.1 \% \mathrm{w} / \mathrm{w})\end{array}$} & \multirow{2}{*}{ ANOVA } \\
\hline & Mean & SE & Mean & SE & Mean & SE & \\
\hline Total cholesterol $(\mathrm{mmol} / \mathrm{l})$ & $6 \cdot 24$ & 0.31 & $6 \cdot 40$ & 0.57 & 4.41 & $0.32^{*} \dagger$ & 0.004 \\
\hline LDL-cholesterol (mmol//) & 0.99 & 0.11 & 0.64 & $0.11^{*}$ & 0.45 & $0.11^{*}$ & 0.010 \\
\hline HDL-cholesterol ( $\mathrm{mmol} / \mathrm{l})$ & 0.42 & 0.04 & $1 \cdot 21$ & $0 \cdot 19^{*}$ & $1 \cdot 13$ & $0 \cdot 10^{*}$ & $<0.001$ \\
\hline HDL : LDL & 0.46 & 0.06 & $2 \cdot 76$ & $0.94^{\star}$ & 3.04 & $0.50^{*}$ & 0.016 \\
\hline HDL : total cholesterol & 0.07 & 0.01 & 0.20 & $0.04^{*}$ & 0.27 & $0.02^{*}$ & $<0.001$ \\
\hline Triacylglycerols (mmol/l) & 11.1 & 1.0 & $14 \cdot 3$ & 1.8 & 5.98 & $0.70^{*} \dagger$ & 0.002 \\
\hline \multicolumn{8}{|c|}{ Non-cholesterol sterols $(\mu \mathrm{mol} / \mathrm{mmol}$ cholesterol) } \\
\hline Desmosterol & 1.76 & 0.10 & $2 \cdot 19$ & 0.17 & $2 \cdot 62$ & $0.20^{*}$ & 0.011 \\
\hline Lathosterol & 0.55 & 0.02 & 0.51 & 0.06 & 0.78 & $0.08^{*} \dagger$ & 0.015 \\
\hline Campesterol & 0.50 & 0.07 & 0.82 & $0.04^{*}$ & 1.05 & $0.08^{*} \dagger$ & $<0.001$ \\
\hline Campestanol & 0.026 & 0.001 & 0.023 & 0.002 & 0.037 & $0.004^{*} \dagger$ & 0.006 \\
\hline Sitosterol & $1 \cdot 30$ & 0.07 & 1.56 & $0.05^{\star}$ & $2 \cdot 24$ & $0.12^{*} \dagger$ & $<0.001$ \\
\hline Sitostanol & 0.24 & 0.01 & 0.22 & 0.02 & 0.33 & $0.04^{*} \dagger$ & 0.007 \\
\hline
\end{tabular}

${ }^{*} P<0.05 v$. the low Ca diet group; $\uparrow P<0.05 v$. the moderate Ca diet group.

$\neq$ For details of diets and procedures, see p. 240.

$0 \cdot 011$, respectively) but not during the high-Ca diet $(P=0.830$ and 0.944$)$. The ratios of serum plant sterols: cholesterol were 3-9-fold increased in both groups supplemented with plant sterols $(P<0 \cdot 01$ for all $)$.

\section{Discussion}

The main purpose of the present study was to examine the influence of dietary $\mathrm{Ca}$ on serum lipid and cholesterol metabolism. Increasing the dietary $\mathrm{Ca}$ intake dosedependently decreased serum total and LDL-cholesterols and triacylglycerols and increased HDL-cholesterol and HDL:LDL. The mechanisms of these favourable effects are not completely understood. Previous studies have suggested that $\mathrm{Ca}$ interferes with cholesterol absorption and metabolism by forming non-absorbable chelates with fatty acids and/or bile acids (Yacowitz et al. 1965; Denke et al. 1993; Denke \& Grundy, 1995; Holt, 1999). It is known that saturated fatty acids increase serum cholesterol, and LDL-cholesterol in particular, by inhibiting the receptor-mediated uptake of LDL into liver cells, thereby decreasing the clearance of LDL particles from the circulation (Kris-Etherton et al. 1988; Grundy \& Denke, 1990). Consequently, decreased absorption of saturated fat would lead to a decrease in serum cholesterol, at least LDL-cholesterol. In the present study, however, the fat content of the diets was rather low, and less than half of the fat was saturated. Therefore, mere blockade of fat absorption may not be sufficient to explain all the favourable effects of $\mathrm{Ca}$, and other mechanisms, such as binding to bile acids, must be considered. Some previous studies have shown that $\mathrm{Ca}$ increases faecal bile acids
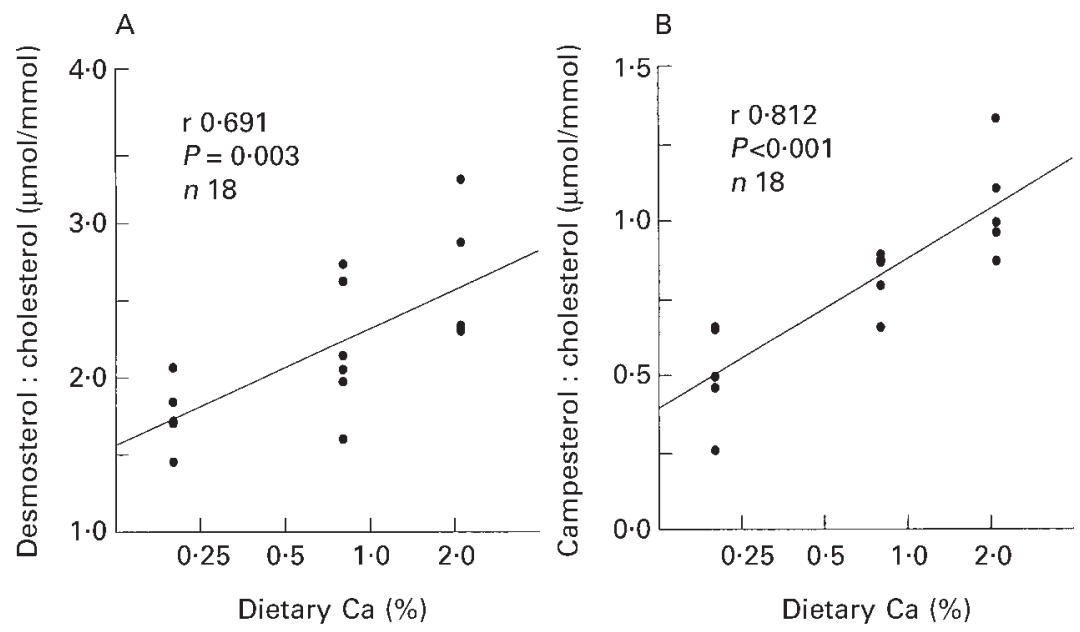

Fig. 3. Dose-dependent effects of dietary calcium on (A) serum desmosterol: cholesterol, reflecting endogenous cholesterol synthesis, and (B) serum campesterol: cholesterol, reflecting intestinal absorption of cholesterol, in obese Zucker rats after 8 weeks on the different diets. For details of diets and procedures, see p. 240 
Table 3. Experiment 4. Serum total-, LDL- and HDL-cholesterol, triacylglycerols, cholesterol precursors and plant sterol concentrations of obese Zucker rats after 8 weeks on the $1 \%$ cholesterol diets with $1 \%$ plant sterol and calcium supplements§

(Mean values with their standard errors for seven or eight rats per group)

\begin{tabular}{|c|c|c|c|c|c|c|c|c|c|}
\hline \multirow[t]{2}{*}{ Diet... } & \multicolumn{2}{|c|}{$\begin{array}{c}\text { Low Ca } \\
(0.2 \% \mathrm{w} / \mathrm{w})\end{array}$} & \multicolumn{2}{|c|}{$\begin{array}{c}\text { High Ca } \\
(2.1 \% \mathrm{w} / \mathrm{w})\end{array}$} & \multicolumn{2}{|c|}{$\begin{array}{l}\text { Low } \mathrm{Ca}+ \\
\text { plant sterols }\end{array}$} & \multicolumn{2}{|c|}{$\begin{array}{l}\text { High } \mathrm{Ca}+ \\
\text { plant sterols }\end{array}$} & \multirow[b]{2}{*}{ ANOVA } \\
\hline & Mean & SE & Mean & SE & Mean & SE & Mean & SE & \\
\hline Total cholesterol $(\mathrm{mmol} / \mathrm{l})$ & $7 \cdot 11$ & 0.67 & $5 \cdot 17$ & $0.52^{*}$ & 4.60 & $0.41^{*}$ & 5.59 & $0.39^{*}$ & 0.012 \\
\hline LDL-cholesterol (mmol/l) & 1.07 & 0.12 & 0.47 & $0.08^{*}$ & 0.40 & $0.04^{*}$ & 0.38 & $0.04^{*}$ & $<0.001$ \\
\hline HDL-cholesterol (mmol/li) & 0.47 & 0.05 & 0.97 & $0 \cdot 14^{*}$ & 0.79 & $0.13^{*}$ & $1 \cdot 30$ & $0 \cdot 09^{*} \dagger \ddagger$ & $<0.001$ \\
\hline HDL: LDL & 0.49 & 0.07 & 2.57 & 0.59 & $2 \cdot 14$ & 0.44 & $4 \cdot 68$ & $1.57^{*} \dagger$ & 0.016 \\
\hline HDL : total cholesterol & 0.07 & 0.01 & $0 \cdot 21$ & $0.04^{*}$ & $0 \cdot 20$ & $0.04^{*}$ & 0.25 & $0.04^{*}$ & 0.002 \\
\hline Triacylglycerols (mmol/l) & 11.8 & 1.3 & $8 \cdot 85$ & 1.72 & $10 \cdot 0$ & 1.3 & $8 \cdot 31$ & $1 \cdot 18$ & 0.258 \\
\hline \multicolumn{10}{|c|}{ Non-cholesterol sterols $(\mu \mathrm{mol} / \mathrm{mmol}$ cholesterol) } \\
\hline Desmosterol & 1.63 & 0.16 & $2 \cdot 29$ & $0.21^{*}$ & 2.51 & $0.17^{*}$ & $2 \cdot 35$ & $0.26^{*}$ & 0.043 \\
\hline Lathosterol & 0.51 & 0.05 & 0.66 & 0.09 & $0 \cdot 81$ & $0.08^{*}$ & 0.66 & 0.07 & 0.075 \\
\hline Campesterol & 0.48 & 0.08 & 0.91 & 0.08 & 3.07 & $0 \cdot 18^{*}$ & 3.74 & $0.34^{\star} \dagger \ddagger$ & $<0.001$ \\
\hline Campestanol & 0.03 & 0.00 & 0.02 & 0.01 & 0.18 & $0.05^{\star}$ & 0.17 & $0.04^{\star} \ddagger$ & 0.006 \\
\hline Sitosterol & $1 \cdot 24$ & 0.10 & 1.98 & 0.19 & $11 \cdot 2$ & $0.4^{\star}$ & 11.6 & $1 \cdot 2^{*} \ddagger$ & $<0.001$ \\
\hline Sitostanal & 0.22 & 0.02 & 0.28 & 0.04 & 0.79 & $0.06^{*}$ & 0.54 & $0.04^{\star} \dagger \ddagger$ & $<0.001$ \\
\hline
\end{tabular}

${ }^{*} P<0.05 v$. the low Ca diet group; $\dagger P<0.05 v$. the low $\mathrm{Ca}+$ plant sterols diet group; $¥ P<0.05 \mathrm{v}$. the high Ca diet group.

$\S$ For details of diets and procedures, see p. 240.

(Saunders et al. 1988; Holt, 1999), while others have reported no changes (Denke et al. 1993). We did not measure fat or bile acid excretion, but we did measure the serum levels of the cholesterol precursors desmosterol and lathosterol, which reflect endogenous cholesterol synthesis, and plant sterols, which can be used as markers of intestinal cholesterol absorption (Miettinen et al. 1990; Gylling et al. 1999). These measurements indicated that Ca dose-dependently increased both the absorption and the synthesis of cholesterol. Nevertheless, at the same time, the serum cholesterol concentration was decreased. This apparently paradoxical effect could be explained by a Ca-induced increase in the excretion of bile acids, which would then lead to increased conversion of cholesterol into bile acids in the liver. This mechanism is known from the lipid-lowering effect of cholestyramine and other bile acidbinding resins (Witztum, 1996).

Enrichment of the high-cholesterol diet with natural plant sterols effectively and dose-dependently lowered the concentration of serum cholesterol in the obese Zucker rats. Previous studies both in animals and in man, using natural plant sterols (Ikeda et al. 1988) or their chemically modified derivatives (Ikeda \& Sugano, 1998; Nguyen, 1999; Law, 2000), have demonstrated that these agents lower serum cholesterol by inhibiting the intestinal absorption of cholesterol (Nguyen, 1999; Law, 2000). However, owing to the reactive increase of cholesterol synthesis in the liver, only mild lowering of serum cholesterol by plant sterols is achieved (Ikeda \& Sugano, 1998). The important finding of the present study was that, although both $\mathrm{Ca}$ and plant sterol supplementations alone had marked effects on serum cholesterols, a further improvement of the serum lipid profile was achieved when $\mathrm{Ca}$ and plant sterols were given concurrently. A similar effect was previously observed during a high-fat diet with a combination of plant sterols, $\mathrm{Ca}$ and $\mathrm{Mg}$ (Vaskonen et al. 2001). As discussed, plant sterols decrease the intestinal absorption of cholesterol (Jones et al. 1997; Ikeda \& Sugano, 1998; Nguyen, 1999; Law, 2000), and Ca may add to the effect by interfering with the absorption of saturated fat, or (which is even more likely during the low-fat diets of the present study) by binding bile acids.

The manifold serum plant sterol levels in the groups supplemented with plant sterols demonstrate that these compounds, while displacing cholesterol from the micelles, are themselves partly absorbed. Some previous reports have postulated that increased serum plant sterol concentrations may contribute to their cholesterol-lowering effect by modifying hepatic lipid metabolism enzymes (Laraki et al. 1993), but also concerns about the safety of these steroid hormone-resembling compounds have been raised (Nguyen, 1999). In the present experiment, no indication of any toxicity of even the highest dietary level of the natural plant sterol composition was found. On the basis of extensive clinical safety evaluation studies, although there is some evidence of lowering of the plasma carotenoid and tocopherol levels, both plant sterols and stanols are generally recognized as safe (Plat et al. 2000).

A diet containing high levels of cholesterol is a major cause of elevated serum cholesterol in man (Sempos et al. 1993). Such a diet also produced a substantial increase of serum cholesterol in the obese Zucker rats. This strain has a recessive single-gene mutation that was first described in 1961 (Zucker \& Zucker, 1961) and has recently been localized in the extracellular domain of the leptin receptor (Phillips et al. 1996). The mutation leads to genetic obesity, hyperlipidaemia, insulin resistance and moderate hypertension (Zucker, 1965; Kasiske et al. 1992), disorders that are also characteristic of the metabolic syndrome in man (DeFronzo \& Ferrannini, 1991). The change of the serum lipid profile in the present study during a low-fat diet, although not as prominent as was found previously with high-fat diets (Vaskonen et al. 2001), confirms these 
previous findings and indicates that this animal can be used as a model for studying cholesterol absorption and metabolism. This is important, because rats are usually considered resistant to hypercholesterolaemia and atherosclerotic diseases. The few other suitable rodent models are also mostly corpulent and leptin-resistant (Clark \& Pierce, 2000).

Taken together, the present experiments showed that increased intake of $\mathrm{Ca}$ during a low-fat, high-cholesterol diet dose-dependently decreased serum total and LDLcholesterol, increased HDL-cholesterol and improved HDL : LDL and HDL: total cholesterol. Ca did not impede the lipid-lowering effects of plant sterols, and even partly augmented the benefits. This was achieved by two different mechanisms of action: (1) a direct inhibiting effect of the intestinal absorption of cholesterol by plant sterols; (2) an indirect serum cholesterol-lowering effect of $\mathrm{Ca}$, probably mediated through increased faecal loss of fatty and bile acids.

\section{Acknowledgements}

The present study was financially supported by grants from the National Technology Agency Tekes, Finland, the Finnish Medical Foundation (T.V.), the Research and Science Foundation of Farmos (T.V.), the Ida Montin Foundation (T.V.), the Academy of Finland (E.M.), and the Sigrid Juselius Foundation (E.M.). We are grateful to Ms Toini Siiskonen, Ms Sanna Alander, Ms Remi Hakama and Ms Marja-Liisa Räsänen for excellent technical assistance.

\section{References}

Clark TA \& Pierce GN (2000) Cardiovascular complications of non-insulin-dependent diabetes: the JCR : LA-cp rat. Journal of Pharmacological and Toxicological Methods 43, 1-10.

DeFronzo RA \& Ferrannini E (1991) Insulin resistance. A multifaceted syndrome responsible for NIDDM, obesity, hypertension, dyslipidemia, and atherosclerotic cardiovascular disease. Diabetes Care 14, 173-194.

Denke MA, Fox MM \& Schulte MC (1993) Short-term dietary calcium fortification increases fecal saturated fat content and reduces serum lipids in men. Journal of Nutrition 123, 1047-1053.

Denke MA \& Grundy SM (1995) In Lowering Cholesterol in High-Risk Individuals and Populations, pp. 183-208 [BM Rifkind, editor]. New York: Marcel Dekker.

Grundy SM \& Denke MA (1990) Dietary influences on serum lipids and lipoproteins. Journal of Lipid Research 31, 1149-1172.

Gylling H, Puska P, Vartiainen E \& Miettinen TA (1999) Serum sterols during stanol ester feeding in a mildly hypercholesterolemic population. Journal of Lipid Research 40, 593-600.

Holt PR (1999) Studies of calcium in food supplements in humans. Annals of the New York Academy of Sciences 889, $128-137$.

Ikeda I \& Sugano M (1998) Inhibition of cholesterol absorption by plant sterols for mass intervention. Current Opinion in Lipidology 9, 527-531.

Ikeda I, Tanaka K, Sugano M, Vahouny GV \& Gallo LL (1988) Inhibition of cholesterol absorption in rats by plant sterols. Journal of Lipid Research 29, 1573-1582.
Jones PJ, MacDougall DE, Ntanios F \& Vanstone CA (1997) Dietary phytosterols as cholesterol-lowering agents in humans. Canadian Journal of Physiology and Pharmacology $\mathbf{7 5}$, 217-227.

Kasiske BL, O'Donnell MP \& Keane WF (1992) The Zucker rat model of obesity, insulin resistance, hyperlipidemia, and renal injury. Hypertension 19, 1110-1115.

Kotchen TA \& McCarron DA (1998) Dietary electrolytes and blood pressure: a statement for healthcare professionals from the American Heart Association Nutrition Committee. Circulation 98, 613-617.

Krauss RM, Eckel RH, Howard B, Appel LJ, Daniels SR, Deckelbaum RJ, et al. (2000) AHA dietary guidelines: revision 2000: A statement for healthcare professionals from the nutrition committee of the American Heart Association. Circulation 102, 2284-2299.

Kris-Etherton PM, Krummel D, Russell ME, Dreon D, Mackey S, Borchers J \& Wood PD (1988) The effect of diet on plasma lipids, lipoproteins, and coronary heart disease. Journal of the American Dietetic Association 88, 1373-1400.

Laraki L, Pelletier X, Mourot J \& Debry G (1993) Effects of dietary phytosterols on liver lipids and lipid metabolism enzymes. Annals of Nutrition \& Metabolism 37, 129-133.

Law M (2000) Plant sterol and stanol margarines and health. British Medical Journal 320, 861-864.

Miettinen TA, Tilvis RS \& Kesäniemi YA (1990) Serum plant sterols and cholesterol precursors reflect cholesterol absorption and synthesis in volunteers of a randomly selected male population. American Journal of Epidemiology 131, 20-31.

Nguyen TT (1999) The cholesterol-lowering action of plant stanol esters. Journal of Nutrition 129, 2109-2112.

Phillips MS, Liu Q, Hammond HA, Dugan V, Hey PJ, Caskey CJ \& Hess JF (1996) Leptin receptor missense mutation in the fatty Zucker rat. Nature Genetics 13, 18-19.

Plat J, Kerckhoffs DA \& Mensink RP (2000) Therapeutic potential of plant sterols and stanols. Current Opinion in Lipidology 11, 571-576.

Saunders D, Sillery J \& Chapman R (1988) Effect of calcium carbonate and aluminum hydroxide on human intestinal function. Digestive Diseases and Sciences 33, 409-413.

Sempos CT, Cleeman JI, Carroll MD, Johnson CL, Bachorik PS, Gordon DJ, Burt VL, Briefel RR, Brown CD \& Lippel K (1993) Prevalence of high blood cholesterol among US adults. An update based on guidelines from the second report of the National Cholesterol Education Program Adult Treatment Panel. Journal of the American Medical Association 269, 3009-3014.

Vaskonen T, Mervaala E, Seppänen-Laakso T \& Karppanen H (2001) Diet enrichment with calcium and magnesium enhances the cholesterol-lowering effect of plant sterols in obese Zucker rats. Nutrition, Metabolism and Cardiovascular Diseases 11, $158-167$.

Witztum JL (1996) In Goodman \& Gilman's The Pharmacological Basis of Therapeutics, 9th ed., pp. 888-889 [JG Hardman, E Limbird, PB Molinoff and RW Ruddon, editors]. New York: McGraw-Hill.

Yacowitz H, Fleischman AI \& Bierenbaum ML (1965) Effects of oral calcium upon serum lipids in man. British Medical Journal 1, $1352-1354$.

Zucker LM (1965) Hereditary obesity in the rat associated with hyperlipidemia. Annals of the New York Academy of Sciences 131, 447-458.

Zucker LM \& Zucker TF (1961) Fatty, a new mutation in the rat. Journal of Heredity 52, 275-278. 